\title{
Polyandry in the ectoparasitic copepod Lepeophtheirus salmonis despite complex precopulatory and postcopulatory mate-guarding
}

\author{
Christopher D. Todd ${ }^{1, *}$, Rebecca J. Stevenson ${ }^{1}$, Helena Reinardy ${ }^{1}$, Michael G. Ritchie ${ }^{2}$ \\ ${ }^{1}$ School of Biology, Gatty Marine Laboratory, University of St Andrews, St Andrews, Fife KY16 8LB, UK \\ ${ }^{2}$ School of Biology, Sir Harold Mitchell Building, University of St Andrews, St Andrews, Fife KY16 9TH, UK
}

\begin{abstract}
Lepeophtheirus salmonis (Krøyer) is an economically important pest on cultured salmonids in the North Atlantic, and has been implicated in declines of some wild salmonid populations. Males inseminate newly-moulted adult females following the cementing of a pair of spermatophores to the female's genital complex. Females can produce multiple pairs of eggstrings over a period of months, but this species is reported to be monogamous as a result of blockage of the female's copulatory ducts by the spermatophore tubules. On wild and farmed Atlantic salmon Salmo salar L., respectively, 88 and $78 \%$ adult females sea lice bore the typical pair of spermatophores, while 11 and $19 \%$ lacked spermatophores. A very few individuals (1\% wild, $3 \%$ farmed) bore 3 or 4 spermatophores, showing that apparently successful multiple mating is possible. Multiple paternity was confirmed by dual-locus microsatellite typing of offspring for 3 of 7 females carrying 4 spermatophores, but also for 2 of 3 females carrying a single pair of spermatophores. Probably most females on wild fish lose their initial spermatophores and are polygamous during their extended ovigerous lifetime, although effective blockage of the copulatory ducts by the first male almost certainly assures single paternity of the first few pairs of eggstrings. The total level of polyandry or sperm competition faced by males may be relatively low. The ecological implications of multiple paternity are discussed within the context of integrated pest management as a strategy of ameliorating L. salmonis infestations impacting both wild and farmed salmonids.
\end{abstract}

KEY WORDS: Paternity - Microsatellite $\cdot$ Spermatophore $\cdot$ Sea lice $\cdot$ Aquaculture Salmonid · Integrated pest management

\section{INTRODUCTION}

The specialist ectoparasitic copepod Lepeophtheirus salmonis (Krøyer) infests all species of wild salmonids in the North Pacific (Nagasawa 2001) and occurs with $100 \%$ prevalence on wild adult salmon Salmo salar L. in the North Atlantic (Jacobsen \& Gaard 1997, Todd et al. 2000). This ectoparasite species, and to a lesser extent the generalist Caligus elongatus Nordmann, remains a major problem to the Atlantic salmon aquaculture industry. At sufficient intensities L. salmonis can debilitate or kill the host fish, and the circumstantial evidence that sea lice are at least a major contributory factor to the recent crashes of wild sea trout Salmo trutta L. stocks in parts of Ireland, Scotland and Norway is now considerable (e.g. Butler 2002, Todd et al. 2004). There is good evidence that $L$. salmonis may be detrimental to wild Atlantic salmon smolts migrating through certain Norwegian fjords (Finstad et al. 2000). Within the broader framework of integrated pest management (IPM), control of sea lice in Scottish aquaculture has focused largely on chemotherapeutants (e.g. organophosphates, pyrethroids, avermectins, hydrogen peroxide) in concert with periodic fallowing of farm sites, single year-class culture within sea lochs and co-ordinated sea lice treatments amongst some farms in voluntary area management agreements (Grant 2002, Lindsay \& Rae 2003). 
Despite these measures, the most recent global estimate of the total economic cost of sea lice to the aquaculture industry exceeds 100 million US \$ per annum (Johnson et al. 2004), and for the Scottish industry alone is at least £25 million per annum (Rae 2002). Effective pest-species control and management demands detailed knowledge of the parasites's life history and population biology, and Lepeophtheirus salmonis has been intensely studied (e.g. Boxshall \& Defaye 1993, Pike \& Wadsworth 1999, Tully \& Nolan 2002), especially in the farm environment (e.g. Revie et al. 2002). The typical pattern for L. salmonis populations infesting wild Atlantic salmon is one of adult $(\sim 90 \%)$ and female ( 70\%) predominance (Jacobsen \& Gaard 1997, Todd et al. 2000), because of an extended life span of ovigerous females. Adult female caligids store sperm in a seminal receptacle (Huys \& Boxshall 1991), have internal fertilisation, and produce multiple pairs of uniseriate eggstrings over their reproductive life. The female retains each eggstring pair and the hatching stage is a free-swimming nauplius larva. After 2 larval moults during an obligatory planktonic phase of 2 to $9 \mathrm{~d}$ (Johnson \& Albright 1991), the infective planktonic copepodid stage is attained and colonisation of the host fish results in the first of 4 sessile chalimus stages. The fourth chalimus moults to the first of 2 mobile preadult stages, and both genders undergo a final moult to the mature adult. Adult male caligids actively locate and attach to Preadult II females for hours or days, and await the definitive adult female moult prior to copulation (Boxshall 1990, Ritchie et al. 1996a). Such precopulatory 'proximate mate-guarding' (e.g. Simmons \& Siva-Jothy 1998) appears to be a defensive behaviour by the male. At copulation, the male cements a pair of spermatophores onto the posterior ventral surface of the female's genital complex and remains clasped postcopula for some hours after spermatophore deposition (Ritchie et al. 1996a). Males take up to $4 \mathrm{~d}$ to synthesise spermatophores following copulation (Hull et al. 1998). Tubules extend from the attached spermatophores and cross the midline to enter the female copulatory pores on opposite sides (see Huys \& Boxshall 1991, p. 274, for L. pectoralis). Emptying of the spermatophore occurs within hours and it is reported that the combination of inner secretions of the spermatophores, the spermatophore tubules themselves, and the male's cement all effectively block the female copulatory ducts and prevent subsequent mating (Ritchie et al. 1996b). Simmons \& SivaJothy (1998) term such behaviour 'remote post-copulatory mate-guarding'.

Ritchie et al. (1996a) deduced that Lepeophtheirus salmonis is monogamous, and Pike \& Wadsworth (1999) concluded that although singly-mated female $L$. salmonis could produce multiple pairs of fertile egg- strings, there was no information to date about female L. salmonis showing multiple mating. Given the importance of a detailed understanding of the mating system for any commercially or ecologically important pest species, and in view of the prevalence of multiple mating throughout the animal kingdom (e.g. Birkhead \& Møller 1998, Neff \& Pitcher 2002) and probable benefits of multiple mating to females (Arnqvist \& Nilsson 2000, Tregenza \& Wedell 2000), we sought to empirically assess whether or not L. salmonis is truly monogamous. Ritchie et al. (1996b) reported that non-virgin female L. salmonis (from farmed salmon) without spermatophores are very rarely found, and also that gravid females were never observed with an empty seminal receptacle. There is no observational evidence, but it is likely that female L. salmonis are incapable of removing the blocking empty spermatophores and cement, and will therefore presumably remain effectively monogamous for at least as long as these remain on the genital complex.

The typical and maximum life spans of female Lepeophtheirus salmonis either on farmed or wild Atlantic salmon remain unknown, but almost certainly extend to several months (Pike \& Wadsworth 1999, Tully \& Nolan 2002), during which time perhaps up to 11 pairs of eggstrings may be produced (Heuch et al. 2000). Adult female L. pectoralis (parasitising plaice Pleuronectes platessa) can survive for up to $10 \mathrm{mo}$ (Boxshall 1974). Anstensrud (1990) showed that spermatophores of $L$. pectoralis remained cemented to the female for a mean of $26 \mathrm{~d}$ (range 2 to $43 \mathrm{~d}$ ), and that females can be copulated more than once, but only after the spermatophores have been lost. The deduction was that male $L$. pectoralis can only temporarily seal the female copulatory ducts as a result of spermatophore deposition. Female L. salmonis may differ markedly from $L$. pectoralis in perhaps retaining their spermatophores throughout reproductive life and remaining monogamous; but assuming that spermatophore retention/loss is similar in L. salmonis and L. pectoralis, monogamy of L. salmonis evidently still is possible if (1) the female copulatory ducts remain permanently blocked following first insemination, (2) all potential eggstrings can be fertilised by sperm stored in the seminal receptacle from the one mating, and (3) if old adult females show an increasing tendency to have lost the spermatophores. Because the last is unlikely to apply (Ritchie et al. 1996a, see last paragraph) this implies that multiple mating of $L$. salmonis may occur commonly, despite laboratory observations of a strong mating preference of males for virgin adult females (Hull et al. 1998). There has been a perception in the Scottish industry that aquaculture sites are liable to self-reinfestation by $L$. salmonis (e.g. Bron et al. 1993, Costello 1993, see also 
Heuch et al. 2003). If this were indeed a significant feature of the infection dynamics of $L$. salmonis on farms then confirmation of obligate female monogamy would have potentially important implications for the possible inclusion of interference of male fertility within a wider IPM strategy.

Our objectives were 2-fold. First, to compare spermatophore occurrence on adult female Lepeophtheirus salmonis from both wild and farmed Atlantic salmon, and second, to ascertain paternity of embryo clutches for individual females from wild hosts. The first few pairs of eggstrings clearly will be fertilised by the initial male but, given the extended life span of adult female $L$. salmonis, and the observations of spermatophore loss in L. pectoralis, it was considered likely that L. salmonis females can lose their spermatophores and be multiply mated during their ovigerous lifetime. However, whether any such subsequent matings result in successful fertilisation by sperm of a second male $\left(\mathrm{P}_{2}\right.$ fertilisation, e.g. Simmons \& Siva-Jothy 1998) remains unclear. Because of their commonly high levels of polymorphism, single-locus DNA microsatellites have long been the method of choice in parentage analyses (e.g. Strassmann et al. 1996). Herein we applied dual-locus genotyping of samples of embryos from single eggstrings for 10 female L. salmonis, using specifically developed microsatellites (Todd et al. 2004).

\section{MATERIALS AND METHODS}

Spermatophore numbers and frequency. Ethanolpreserved adult female Lepeophtheirus salmonis from wild and farmed Atlantic salmon were examined for spermatophores. Bulk samples (not separated for each host fish) were obtained from 2 Scottish salmon farms. One farm sample (June 1998; Farm 3 of Todd et al. 2004) was from the mainland coastline of Wester Ross, and the other from the Western Isles (September 1997; Farm 5 of Todd et al. 2004). Complete collections of $L$. salmonis from individual wild Atlantic salmon were obtained from the commercial coastal nets at Strathy Point, north Scotland $\left(58^{\circ} 06^{\prime} \mathrm{N}, 04^{\circ} 00^{\prime} \mathrm{W}\right)$ in July 1999 , 2002, 2003 and 2004.

Female Lepeophtheirus salmonis from wild salmon were distinguished as 'young' and 'old' adults, according to the degree of expansion of the genital complex (see Ritchie et al. 1996a,b), which proceeds in newly moulted adult females irrespective of copulation. The Preadult I and II female stages were distinguished for the Strathy Point 2002 to 2004 samples, but in 1999 only total preadult females were recorded. All adult females were scored as bearing 0 to 4 spermatophores. Females carrying the typical single pair of spermatophores (see Huys \& Boxshall 1991, p. 279) are referred to here as 'paired spermatophore' individuals. Individuals bearing an additional 1 or 2 spermatophores generally had these cemented along the outer edge of the initial pair of spermatophores; these we refer to as 'multiple spermatophore' females.

Microsatellite typing of females and their families. Multiple spermatophore females clearly had been multiply mated, and 7 such females were specifically chosen for microsatellite genotyping. Our primary requirements were to assess whether or not (1) specifically chosen females that had unequivocally mated multiply, and (2) randomly chosen females that carried the typical pair of spermatophores, were monogamous or producing polyandrous clutches of offspring. In 3 instances of multiply mated females (Females 4, 5, 6), we randomly sampled from the same respective fish another ovigerous, paired-spermatophore female (Females 1, 2, 3; Table 1).

For microsatellite PCR, a variable number of offspring embryos (5 to 10 ) from both the proximal (attached) and distal (free) ends of 1 of the 2 available eggstrings were isolated for each of 10 females. Of the 7 multiple spermatophore females, 4 (Nos. 4, 5, 6, 9) had broken eggstrings: for these the individual embryos were isolated from both the proximal and the broken end, but were known to not have been maxi-

Table 1. Lepeophtheirus salmonis. The 10 females and single eggstrings used for paternity analysis. All were sampled from returning wild adult Atlantic salmon Salmo salar netted at Strathy Point, North Scotland. For host fish, year of sampling, fish identifier and host sea-age $(1 \mathrm{SW}, 2 \mathrm{SW}=1 / 2$ sea-winter[s]) are given. For female parasites, condition of sampled eggstring, egg complement (intact eggstrings only; na $=$ not available), number of spermatophores borne and numbers of offspring genotyped (positions within eggstring) are shown

\begin{tabular}{|c|c|c|c|c|c|}
\hline $\begin{array}{l}\text { Female } \\
\text { sea } \\
\text { louse }\end{array}$ & $\begin{array}{c}\text { e Year/ } \\
\text { Fish no./ } \\
\text { Sea-age }\end{array}$ & $\begin{array}{l}\text { Egg- } \\
\text { string }\end{array}$ & $\begin{array}{l}\text { Total } \\
\text { egg no. }\end{array}$ & $\begin{array}{l}\text { No. of } \\
\text { spermato- } \\
\text { phores }\end{array}$ & $\begin{array}{l}\text { No. offspring typed } \\
\text { (position) }\end{array}$ \\
\hline 1 & 2001/02/2SW & Intact & 202 & 2 & $10(5$ proximal +5 distal $)$ \\
\hline 2 & 2001/39/1SW & Intact & 445 & 2 & 10 (5 proximal +5 distal $)$ \\
\hline 3 & 2001/28/1SW & Intact & 528 & 2 & $10(5$ proximal +5 distal $)$ \\
\hline 4 & $2001 / 02 / 2 \mathrm{SW}$ & Broken & na & 4 & 10 \\
\hline 5 & $2001 / 39 / 1 \mathrm{SW}$ & Broken & na & 4 & 10 \\
\hline 6 & $2001 / 28 / 1 \mathrm{SW}$ & Broken & na & 4 & 10 \\
\hline 7 & 1999/33/1SW & Intact & 261 & 4 & 16 (8 proximal + 8 distal) \\
\hline 8 & 2001/31/1SW & Intact & 429 & 4 & 20 (10 proximal +10 distal $)$ \\
\hline 9 & 2002/59/1SW & Broken & na & 4 & 20 \\
\hline 10 & $2002 / 63 / 1 \mathrm{SW}$ & Intact & 325 & 4 & 20 (10 proximal +10 distal $)$ \\
\hline
\end{tabular}


mally separated within the original eggstring. For Females 1-3 (2 spermatophores) and 7, 8 and 10 (multiple spermatophores), the sampled offspring were contiguous and equally balanced from the 2 ends of the intact eggstring (Table 1) to provide offspring genotypes for the first and last fertilised embryos within those eggstrings.

PCR was undertaken for genomic DNA of individual embryos from other females in a preliminary study, with extraction by means of either a NucleoSpin (Abgene) kit or by the 'single fly' preparation (Gloor \& Engels 1992). The latter methodology consistently resulted in the clearer PCR products and was subsequently adopted throughout. Female parent tissue for PCR genotyping was obtained by excising an appropriately small piece of the anterior cephalothorax and also by removal of a maxilliped. These were extracted with the same protocol as the individual embryos and the single limb was found to consistently provide the clearer PCR products. PCR for all families included primers for 2 highly polymorphic Lepeophtheirus salmonis microsatellites (see Todd et al. 2004 for primer sequences and details of PCR amplifications). LsalSTA3 (GenBank Accession No. AY509256) and LsalSTA5 (AY509258), respectively, had shown 38 and 43 alleles in a previous analysis of population structuring of L. salmonis from throughout the North Atlantic. PCR products were visualised by PAGE silver-staining and alleles were sized against $10 \mathrm{bp}$ ladders and against a previously genotyped individual as a positive control.

Statistical analyses. Spermatophore frequencies for the separate years and for 'wild' and 'farmed' Lepeophtheirus salmonis were analysed for heterogeneity by the $G$-test. For families with apparently single paternity, statistical power was assessed by means of the Monte Carlo simulation model of Neff \& Pitcher (2002). The probability of detecting multiple paternity within a clutch (Neff \& Pitcher's PrDM) is a function of the numbers of (1) loci used, (2) alleles in the population, (3) offspring genotyped, and (4) effective males. Moreover, males may have differential fertilisation success. Neff \& Pitcher's programme is dimension-limited to 30 alleles per locus. For present purposes we deleted alleles with the lowest frequencies from our original Atlantic frequency distributions for the 2 loci (Todd et al. 2004), and thereby reduced population diversity from 38 to 26 alleles (for LsalSTA3) and 43 to 27 alleles (for LsalSTA5), respectively. Population allele frequencies were recalculated for the 2 truncated distributions and included in the model. Each simulation included the known maternal genotype for the 2 loci and 2 (genetically unknown) males were presumed for each set of offspring analysed; the probability of detecting dual paternity was computed assuming both equal (0.5:0.5) and highly skewed (0.9:0.1) fertilisation success of 2 males. The tabulated probabilities are the averages for 10 runs of the model.

\section{RESULTS}

\section{Spermatophore numbers and frequency}

Most adult female Lepeophtheirus salmonis from wild and farmed host fish bore a pair of spermatophores (Table 2), cemented in the typical posterioventral position on the genital complex. It is generally impossible to visually assess whether females carrying the typical paired spermatophores were (1) singly mated, or (2) had possibly lost their initial spermatophores plus cement-perhaps some weeks after copulation (see Anstensrud 1990 for L. pectoralis)and been multiply copulated. Some individuals evidently had lost one of the pair, as indicated by traces of remaining male cement. Few females lacked spermatophores, but many of these also showed traces of cement, indicating that they had been inseminated at least once.

A very low percentage of females from both wild and farmed salmon did, however, carry multiple (3 or 4 ) spermatophores, and almost certainly had been mated by at least 2 separate males. There was significant heterogeneity amongst the 4 yr for wild salmon (Table 2 ; $G=15.09,6 \mathrm{df}, \mathrm{p}=0.020$ ): 2002 to 2004 did not differ significantly from one another, but 1999 differed significantly from all 3 , due to fewer than expected individuals lacking spermatophores in 1999. There was no significant heterogeneity between the 2 farm samples

Table 2. Lepeophtheirus salmonis. Adult females from wild and farmed Atlantic salmon Salmo salar, showing \% (frequency) bearing 0 to 4 spermatophores

\begin{tabular}{|c|c|c|c|c|c|c|c|c|}
\hline \multirow{2}{*}{$\begin{array}{l}\text { Sperma- } \\
\text { tophores }\end{array}$} & \multicolumn{5}{|c|}{ Strathy Point (wild fish) - } & \multicolumn{3}{|c|}{ —Farm (fish) } \\
\hline & $\begin{array}{c}1999 \\
(\mathrm{n}=42)\end{array}$ & $\begin{array}{c}2002 \\
(\mathrm{n}=53)\end{array}$ & $\begin{array}{c}2003 \\
(\mathrm{n}=64)\end{array}$ & $\begin{array}{c}2004 \\
(\mathrm{n}=62)\end{array}$ & $\begin{array}{l}\text { Pooled } \\
(\mathrm{n}=221)\end{array}$ & $\begin{array}{c}5 \\
(\mathrm{n}=14)\end{array}$ & $\begin{array}{c}3 \\
(\mathrm{n}=11)\end{array}$ & $\begin{array}{c}\text { Pooled } \\
(\mathrm{n}=25)\end{array}$ \\
\hline 0 & $\begin{array}{l}8.0 \\
(60)\end{array}$ & $\begin{array}{l}13.0 \\
(81)\end{array}$ & $\begin{array}{l}11.8 \\
(107)\end{array}$ & $\begin{array}{c}10.3 \\
(112)\end{array}$ & $\begin{array}{l}10.7 \\
(360)\end{array}$ & $\begin{array}{l}22.4 \\
(26)\end{array}$ & $\begin{array}{c}12.0 \\
(6)\end{array}$ & $\begin{array}{l}19.3 \\
(32)\end{array}$ \\
\hline $\begin{array}{l}1 \text { or } 2 \\
\text { ('paired') }\end{array}$ & $\begin{array}{l}90.5 \\
(677)\end{array}$ & $\begin{array}{c}86.4 \\
(538)\end{array}$ & $\begin{array}{l}87.2 \\
(788)\end{array}$ & $\begin{array}{l}89.1 \\
(971)\end{array}$ & $\begin{array}{c}88.4 \\
(2974)\end{array}$ & $\begin{array}{l}74.1 \\
(86)\end{array}$ & $\begin{array}{l}86.0 \\
(43)\end{array}$ & $\begin{array}{l}77.7 \\
(129)\end{array}$ \\
\hline $\begin{array}{l}3 \text { or } 4 \\
\text { ('multiple') }\end{array}$ & $\begin{array}{c}1.5 \\
(11)\end{array}$ & $\begin{array}{l}0.6 \\
(4)\end{array}$ & $\begin{array}{l}1.0 \\
(9)\end{array}$ & $\begin{array}{l}0.6 \\
(6)\end{array}$ & $\begin{array}{c}0.9 \\
(30)\end{array}$ & $\begin{array}{l}3.4 \\
(4)\end{array}$ & $\begin{array}{l}2.0 \\
(1)\end{array}$ & $\begin{array}{l}3.0 \\
(5)\end{array}$ \\
\hline
\end{tabular}


$(G=3.04,2 \mathrm{df}, \mathrm{p}=0.219)$, although the sample sizes are small. Comparison of the pooled frequencies for parasites sampled from wild versus farmed hosts showed significant heterogeneity $(G=15.56,2 \mathrm{df}, \mathrm{p}<0.001)$, with farm lice showing more than expected females lacking spermatophores or carrying multiple spermatophores.

Multiple spermatophore individuals almost invariably were old adult females (fully expanded genital complex), although 1 young adult female (small genital complex) was recorded in this category for 2002. Distinguishing the wild adult females into 'young' and 'old' (Table 3) showed that whilst approximately onethird of young adult females remained virgin, only $8 \%$ of old females were lacking spermatophores. The latter had not, however, all recently undergone the definitive moult from the Preadult II stage because, for example, $13 \%$ of the 87 old adult females lacking spermatophores in 2003 bore both cement and copulation marks from the male appendages on their genital complex. Together, these features strongly indicate that these 'old' females had been previously mated but had lost their spermatophores.

\section{Microsatellite typing and analysis of paternity}

For LsalSTA3 and LsalSTA5, respectively, 15 and 18 different alleles were detected amongst the 10 females and their families (Table 4): 3 other alleles at LsalSTA5 were recorded as maternal. Multiple paternity was confirmed among the families for 2 of the 3 females bearing the typical pair of spermatophores.
Table 3. Lepeophtheirus salmonis. Adult females from wild Atlantic salmon Salmo salar netted at Straithy Point over 4 yr period, showing \% (frequency) of 'young' and 'old' lacking (without) or bearing (with) spermatophores

\begin{tabular}{|lllll|}
\hline \multirow{2}{*}{ Year } & \multicolumn{2}{c}{ - Percent young (n) - } & \multicolumn{2}{c|}{ - Percent old (n) - } \\
& without & with & without & with \\
\hline 1999 & $25.6(11)$ & $74.4(32)$ & $7.0(49)$ & $93.0(656)$ \\
2002 & $38.9(35)$ & $61.1(55)$ & $8.6(46)$ & $91.4(487)$ \\
2003 & $30.3(20)$ & $69.7(46)$ & $10.4(87)$ & $89.6(751)$ \\
2004 & $24.3(43)$ & $75.7(134)$ & $7.6(69)$ & $92.4(843)$ \\
Pooled & $29.0(109)$ & $71.0(267)$ & $8.4(251)$ & $91.6(2737)$ \\
\hline
\end{tabular}

The test of paternity for the third family in this category (Female 3) was, however, weak due to the lack of data for LsalSTA5 (failed PCR). The single inferred male for Family 8 was homozygous at LsalSTA3 and shared an allele at that locus with Female 8.

For Females 1 and 2 (Table 4) single paternity was implied for 1 of the 2 loci, and yet dual paternity was confirmed by the alternative locus, showing that the males again shared alleles at 1 locus despite the potentially high allele numbers. Neff \& Pitcher's PrDM for Female 3 was high (>90\%), but only when assuming equal mating success of 2 putative fathers. For the strongly skewed simulation, the probability of detecting multiple paternity for these 10 offspring fell to $52 \%$. For Females 8 and 10, confidence in single paternity was consistently high for both simulations because of the larger families screened.

The relative frequencies of the male alleles (both loci) for each family of offspring are shown in Fig. 1. In all 5 cases of multiple paternity -2 of 3 paired spermatophore females (Nos. 1, 2) and 3 of 7 multiple spermatophore (Nos. 4, $7,9)$ individuals - all offspring could be genetically explained by just 2 males. Although the family samples are small it is important to note that, for the multiply mated females, the least successful paternal allele always had a very low frequency ( 0.08 for both loci; Fig. 1). If these females had mated only twice (no families showed $>4$ paternal alleles), and males had equal fertilisation success, this frequency would be expected to approximate 0.25. Hence, male fertilisation success probably is not equal in this species, but there are numerous processes (variation in sperm depletion or quality, insemination rates, sperm competition, cryptic female choice) which could be responsible for this pattern. 


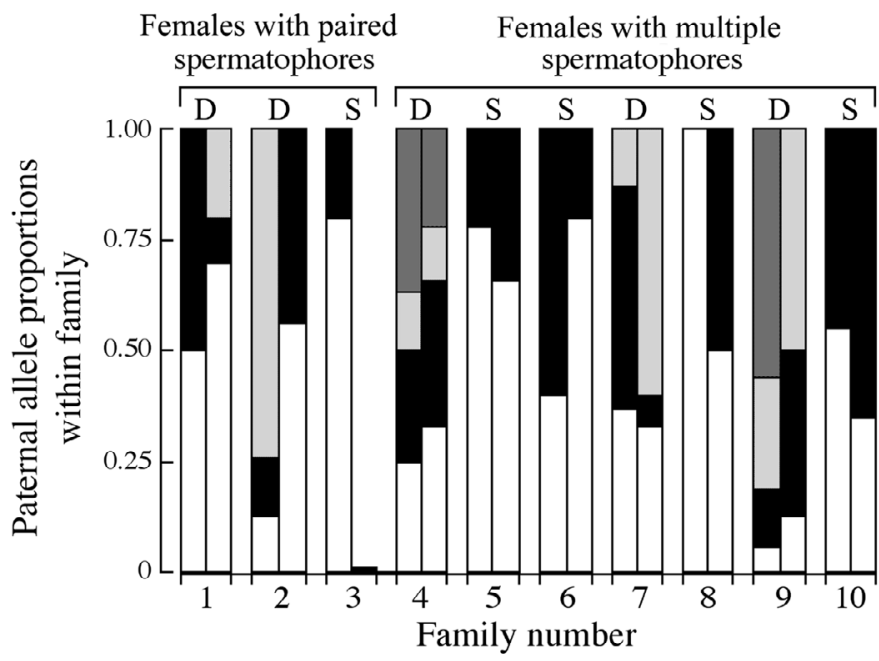

Fig. 1. Lepeophtheirus salmonis. Proportional frequencies of male alleles for LsalSTA3 (left-hand bar) and LsalSTA5 (right-hand bar) for offspring families of Females 1 to 10 . Shading shows number and proportions of male alleles for each family; similar shading does not imply identical alleles across families; 1 or 2 non-maternal alleles = single paternity, $\mathrm{S}$ (Females 3, 5, 6, 8, 10); 3 or 4 non-maternal alleles = dual paternity, D (Females 1, 2, 4, 7, 9). Females 1 to 3 bore single pair of spermatophores; Females 4 to 10 bore 4 spermatophores. Data for LsalSTA5 for Family 3 missing due to failed PCR

\section{DISCUSSION}

\section{Multiple mating and paternity}

If the cemented spermatophores of Lepeophtheirus salmonis are successful in preventing subsequent male insemination, the simplest explanation of the paternity data is as follows: (1) Of the 7 multiply mated females, 4 (Females 5, 6, 8, 10) still bore their original spermatophores and a subsequent pair. Their copulatory pores remained blocked by the original pair, and despite having been multiply mated they were effectively still monogamous. (2) For the remaining 3 multiply mated females (Females 4, 7, 9), the spermatophores borne were the second and third pairs, and dual paternity of offspring was attributable to the first (lost) and second pairs of spermatophores. The second pair did, however, still block the copulatory pores from the most recently acquired third pair. (3) Of those bearing the typical single pair of spermatophores, Female 3 had been mated only once, whereas Females 1 and 2 bore a replacement second pair, having lost the initial pair of spermatophores and were producing offspring which had been successfully fertilised by the second male $\left(\mathrm{P}_{2}\right.$ fertilisation).

The higher percentage of adult females from farmed hosts carrying no spermatophores (19\%; Table 2) was unexpected, given observations of the often very marked predominance of males on farmed salmon (e.g. Bron et al. 1993) in contrast to female predominance on wild salmon (e.g. Todd et al. 2000), and the presumed reduced life span of parasites on farmed fishes. Despite $29 \%$ of young adult females on wild salmon being unmated (Table 3 ), it is very probable that within the $8 \mathrm{~d}$ (at $12^{\circ} \mathrm{C}_{\text {; }}$ Ritchie et al. 1996a) required for full expansion of the genital complex and the transformation of an adult female from 'young' to 'old', all females on wild fish will become inseminated. The likelihood is, therefore, that old adult females lacking spermatophores are seldom, if ever, virgin, but will be previously inseminated individuals that have lost both the spermatophores and their cement, and may well already be polyandrous.

Numerical predominance of females over males appears widespread in populations of free-living calanoid copepods (e.g. Cuoc et al. 1997, Bathélémy et al. 1998). Because the mobile preadult and adult stages of Lepeophtheirus salmonis almost certainly do not transfer between wild host fish (but see Ritchie 1997 for hosts in farm pens), the individual fish is the effective demographic 'unit' for these ectoparasites. It clearly is possible that on a given fish there may be insufficient adult males to pair with all the reproductively 'available' female complement (Preadult II females, plus unfertilised young adult females and 'old' adult females lacking spermatophores): this could therefore lead to incidences of old virgin adult females. Every wild fish sampled at Strathy Point in 2002 to 2004 bore 1 or more adult male sea lice (range 1 to 25), and always adult males on a given fish numerically exceeded Preadult II females (data not shown). Similarly, the number of adult males almost always exceeded the complement of females reproductively available to those males on a given fish (Fig. 2). Predictions of male:male competition, and of female-mating frequency, in both freeliving and parasitic copepods may, therefore, be erroneous if such expectations are based on population proportions of total males and females. For L. salmonis specifically, the general surfeit of adult males over available females on individual fish, and the consistent occurrence of a large proportion of unfertilised young adult females (Table 3), shows that successful fertilisation of adult females does not always occur as soon as they undergo the final moult from the Preadult II stage. The rare occurrence of multiple spermatophores (Table 2) does, however, confirm that adult females already bearing spermatophores may very occasionally be multiply mated. Taken together, these data, and the low frequency of old adult females lacking spermatophores (Tables $2 \& 3$ ), all strongly indicate that multiple mating is a common feature in L. salmonis, despite clear laboratory behavioural preferences by adult males for the younger female stages (Hull et al. 1998). 


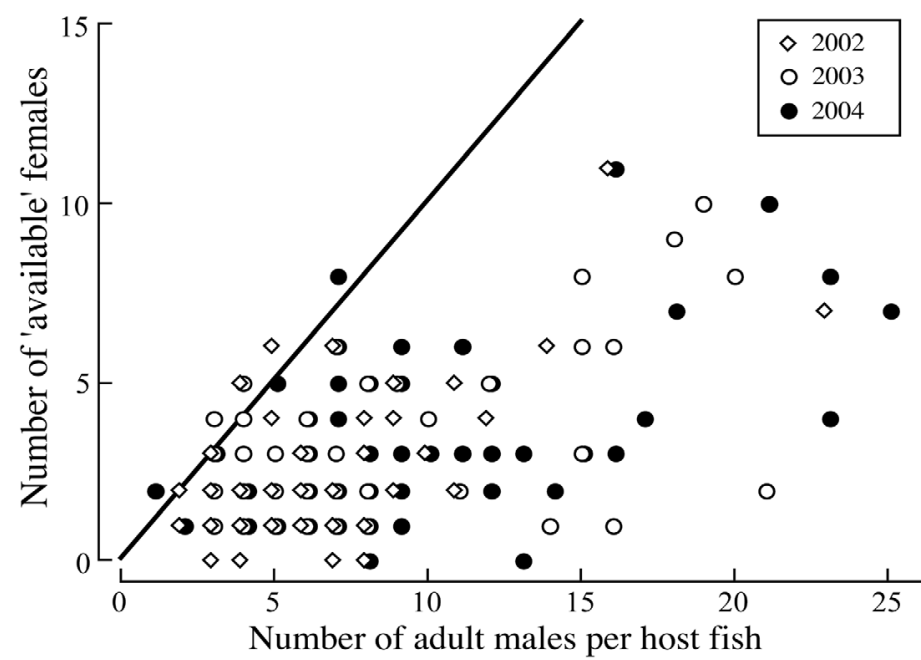

Fig. 2. Lepeophtheirus salmonis on wild Atlantic salmon Salmo salar for period 2002 to 2004 inclusive (n = 179 fish; Table 2). Scatterplot of 'available' females (= Preadult II females + 'young' adult females [0 spermatophores] + 'old' adult females [0 spermatophores]) on adult males per host fish. Fitted line indicates equality of numbers of males and 'available' females. Abscissa values for Years 2002 and 2004 offset for clarity

Further data for both wild and farmed host fish are required, but if the observed two-thirds of paired spermatophore females (Nos. 1 and 2) showing dual paternity is representative, it is likely that most females on wild and farmed salmon will be polyandrous. Probably only those females that fail to survive beyond loss of the initial spermatophores and their cement will be effectively monogamous. In the farm environment, therefore, routine chemotherapy and its consequential restriction of the adult life span might result in effective monogamy of females. Spermatophores on a female are visible evidence of the outcome of precopulatory competition amongst various males on a host fish; but the finding of multiple paternity of offspring does not, in itself, necessarily reflect postcopulatory male competition, sperm competition, or even cryptic female choice (e.g. Eberhard 1998). Only detailed manipulative studies of the copulation and fertilisation history of individual females, and of changes in individual male availability through their ovigerous lifetimes, will reveal the nature and extent of such interactions. It will, for example, be of especial importance to ascertain the extent of initial sperm depletion prior to loss of the first pair of spermatophores in relation to possible sperm displacement and competition, male precedence, and the mean and variance of second male paternity $\left(\mathrm{P}_{2}\right.$ fertilisation, e.g. Simmons \& Siva-Jothy 1998, Simmons 2001).

The temporal and energetic investment by male caligids in proximate mate-guarding of the Preadult II female, and the subsequently inseminated young adult female, is relatively small-a matter of hours, or perhaps days (Boxshall 1990, Ritchie et al. 1996a). Conversely, the durability of the attached spermatophores and cement provides the individual male with extended, cheap and effective remote postcopulatory mate-guarding (cf. Hull et al. 1998), perhaps for some weeks, during which the (initially monogamous) female may produce several pairs of eggstrings. Insect mating plugs do generally represent effective shortterm barriers to re-insemination (Simmons 2001), but for the majority of insects (which have a single female genital opening), long-term barriers might also prevent the female from ovipositing and thereby be detrimental to both male and female reproductive success. In sharp contrast to most insects, however, female caligid copepods have separate paired copulatory ducts and gonopores through which the fertilised eggstrings are extruded. Effective first-male blockage of the female does not, therefore, compromise either first male or female fitness in Lepeophtheirus salmonis. Nonetheless, loss of the blockage does allow a degree of polygamy.

\section{Monogamy and pest control}

IPM approaches to pest control are deliberately multifaceted and, amongst other benefits, aim to reduce reliance on insecticides and the evolution of treatment resistance by the target organism. The sterile insect technique (SIT) typically involves the rearing and sterilisation of males by irradiation before their subsequent release to the environment (e.g. Curtis 1985); SIT has proved to be a successful means of controlling certain terrestrial pest species (e.g. Ferguson et al. 2005), especially when applied within a broader IPM strategy (e.g. Dargie 2000, Twohey et al. 2003). An effective contribution to pest control by sterile male release (SMR) in the aquatic environment is, however, restricted to attempts to control sea lampreys Petromyzon marinus parasitising lake trout and lake whitefish in the Laurentian Great Lakes (e.g. Twohey et al. 2003). Migrating male lampreys are trapped, chemically sterilised by individual injection and then released. An attractive element of the SMR approach is its potentially minimal wider environmental effect (Siefkes et al. 2003). Of the licensed sea louse chemotherapeutants available to the Scottish industry, only 2 (cypermethrin, emamectin-both of which nonspecifically interfere with the neural membrane function) are widely used. Teflubenzuron, a chitin synthesis inhibitor, which is accordingly ineffective against the (non-moulting) adult stage, is in use only intermittently (Grant 2002). It is therefore understandable that 
the industry has concerns over possible self-reinfestation of farm sites and development of resistance to the few compounds available to them. Whilst the direct experimental evidence of resistance of sea lice to chemical treatments (e.g. dichlorvos, Jones et al. 1992; deltamethrin, Sevatdal et al. 2005) is equivocal, there is a perception within the industry that this can be a problem. An IPM strategy that ameliorates larval sea lice production, and that minimises dependence on agents to which resistance may evolve, could be advantageous to the aquaculture industry.

Monogamy of a pest species renders it especially vulnerable to SMR, but it can have an adverse consequence in genetic control if already-mated females immigrate from without the treatment area (Curtis 1985), or if females begin to avoid sterile males (Ferguson et al. 2005). Unlike many insect pests, which may be highly vagile, adult Lepeophtheirus salmonis are effectively sedentary (and thereby manageable and readily treatable) on their host fish in captivity, because it is only the planktonic larval stages that emigrate and immigrate. For polyandrous caligid copepods, SMR, or deployment of male sterilant treatments, might yet offer a plausible addition to current sea lice IPM by the aquaculture industry if extremely high sterile:wild ratios of males could be attained on fish within the treatment area. It will never be feasible to rear (on live fish) and release the required numbers of manipulated males for SMR approaches; and, because of their poor abilities to reattach to host fish (Pike \& Wadsworth 1999), released adult males almost certainly will not establish themselves on farms in suitable numbers. Because populations of $L$. salmonis on salmon farms are demographically open (Todd et al. 2004), it will never be possible to eradicate this pest at aquaculture sites. However, it may be possible to develop a specific, biologically or photochemically degradable male sterilant. The wider environmental impact of such an agent could perhaps be reduced by its targeted application as an in-feed additive, but application would have to be regular in order to continually sterilise males as they develop on the fish from the immigrating infective copepodid larval stages.

Our previous study of Atlantic and Pacific Lepeophtheirus salmonis (Todd et al. 2004) revealed that levels of gene flow and cross-infection amongst the different host species and between wild and farmed salmonids are sufficiently high throughout the North Atlantic to prevent significant population genetic differentiation on an ocean-wide scale. Planktonic larvae of $L$. salmonis exported by currents from a given farm site may well infect both adjacent farms and local populations of wild salmonids, in addition to perhaps ultimately being re-imported and re-infesting the natal farm site. High levels of gene flow (= larval colonisation) between wild and farmed salmonids, together with the considerable numerical imbalance between wild and cultured salmonids in the coastal waters of Scotland (e.g. Butler 2002), lead to the conclusion that the bulk of the larval flux of $L$. salmonis is probably from farmed to wild hosts. Notwithstanding the logistic and practical difficulties in achieving SMR in the aquatic environment, the incorporation of male sterilisation of $L$. salmonis within a commercially beneficial and environmentally benign IPM strategyincluding co-ordinated area management agreements amongst farm sites-may therefore have significant mutual benefits for the welfare of both wild and farmed salmonid stocks. The effectiveness of the contribution to control by sterilising male parasites as they develop on the host fish would also be enhanced if chemotherapeutants could be used to ensure that ovigerous females generally did not survive beyond loss of their initial spermatophores.

From an ecological perspective, only experimental manipulation and long-term maintenance of individual copepods on isolated host fish will allow a full understanding of the possible roles of sperm depletion, competition, displacement or stratification, and patterns of male sperm precedence or cryptic female choice in this economically and environmentally important pest species. The key finding - that polyandry occurs and probably is widespread amongst female Lepeophtheirus salmonis - is important to the modelling of the dynamics and the management of caligid infestations on cultured salmonids (e.g. Revie et al. 2002), and requires quantification in the farm environment. Polyandrous mating of adult females also has implications for the evolution and possible spread of resistance to chemotherapeutant treatments on an ocean-wide scale. Furthermore, the fact that polyandry is frequent despite post-copulatory mate-guarding in this species should urge caution regarding inferences of single or multiple matings (e.g. Cuoc et al. 1997, Bathélémy et al. 1998) in other free-living copepods based on anatomical observations alone.

Acknowledgements. We thank A. E. Magurran, G. A. Boxshall and A. M. Walker for comments on the manuscript and J. A. Graves for molecular advice and assistance. G. B. Shimmield and the Scottish Association for Marine Science, Oban, kindly provided a SAMS Bursary to C.D.T. and R.J.S. We are grateful to S. Paterson (T. R. Paterson \& Sons, Salmon Fishing Station, Strathy Point) for access to fish from his netting operation.

\section{LITERATURE CITED}

Anstensrud M (1990) Mating strategies of two parasitic copepods [(Lernaeocera branchialis (L.) (Penellidae) and Lepeophtheirus pectoralis (Müller) (Caligidae)] on flounder: 
polygamy, sex-specific age at maturity and sex ratio. J Exp Mar Biol Ecol 136:141-158

Arnqvist G, Nilsson T (2000) The evolution of polyandry: multiple mating and female fitness in insects. Anim Behav 60:145-164

Bathélémy RM, Cuoc C, Defaye D, Brunet M, Mazza J (1998) Female genital structures in several families of Centropagoidea (Copepoda: Calanoida). Phil Trans R Soc Lond B 353:721-736

Birkhead TR, Møller AP (1998) Sperm competition, sexual selection and different routes to fitness. In: Birkhead TR, Møller AP (eds) Sperm competition and sexual selection. Academic Press, London, p 757-781

Boxshall GA (1974) The population dynamics of Lepeophtheirus pectoralis (Müller): seasonal variations in abundance and age structure. Parasitology 69:361-371

Boxshall GA (1990) Precopulatory mate guarding in copepods. Bijdr Dierkd 60:209-213

Boxshall GA, Defaye D (eds) (1993) Pathogens of wild and farmed fish: sea lice. Ellis Horwood, Chichester

Bron JE, Sommerville C, Wootten R, Rae GH (1993) Influence of treatment with dichlorvos on the epidemiology of Lepeophtheirus salmonis (Krøyer, 1837) and Caligus elongatus Nordmann, 1832 on Scottish salmon farms. In: Boxshall GA, Defaye D (eds) Pathogens of wild and farmed fish. Sea lice. Ellis Horwood, Chichester, p 263-274

Butler JRA (2002) Wild salmonids and sea louse infestations on the west coast of Scotland: sources of infection and implications for the management of marine salmon farms. Pest Manag Sci 58:595-608

Costello MJ (1993) Review of methods to control sea lice (Caligidae: Crustacea) infestations on salmon (Salmo salar) farms. In: Boxshall GA, Defaye D (eds) Pathogens of wild and farmed fish. Sea lice. Ellis Horwood, Chichester, p 219-252

Cuoc C, Defaye D, Brunet M, Notonier R, Mazza J (1997) Female genital structures of Metridinidae (Copepoda: Calanoida). Mar Biol 129:651-665

Curtis CF (1985) Genetic control of insect pests: growth industry or lead balloon? Biol J Linn Soc 26:359-374

Dargie J (2000) Nuclear technologies and food security: fields of progress. IAEA Bull 42:23-32

Eberhard WG (1998) Female roles in sperm competition. In: Birkhead TR, Møller AP (eds) Sperm competition and sexual selection. Academic Press, London, p 91-116

Ferguson HM, John B, Ng'habi K, Knols BGJ (2005) Redressing the sex imbalance in knowledge of vector biology. Trends Ecol Evol 20:202-209

Finstad B, Bjørn PA, Grimnes A, Hvidsten NA (2000) Laboratory and field investigations of salmon lice [Lepeophtheirus salmonis (Krøyer)] infestation on Atlantic salmon (Salmo salar L.) post-smolts. Aquac Res 31:795-803

Gloor G, Engels W (1992) Single-fly DNA preparations for PCR. Drosophila Inf Serv 71:148-149

Grant AN (2002) Medicines for sea lice. Pest Manag Sci 58: 521-527

Heuch PA, Nordhagen JR, Schram TA (2000) Egg production in the salmon louse [Lepeophtheirus salmonis (Krøyer)] in relation to origin and water temperature. Aquac Res 31: 805-814

Heuch PA, Revie CW, Gettinby G (2003) A comparison of epidemiological patterns of salmon lice, Lepeophtheirus salmonis, infections on farmed Atlantic salmon, Salmo salar L., in Norway and Scotland. J Fish Dis 26:539-551

Hull MQ, Pike AW, Mordue AJ, Rae GH (1998) Patterns of pair formation and mating in an ectoparasitic caligid copepod Lepeophtheirus salmonis (Krøyer 1837): implications for its sensory and mating biology. Phil Trans R Soc Lond B 353:753-764

Huys R, Boxshall GA (1991) Copepod evolution. Ray Society, London

Jacobsen JA, Gaard E (1997) Open-ocean infestation by salmon lice (Lepeophtheirus salmonis): comparison of wild and escaped farmed Atlantic salmon (Salmo salar L.). ICES J Mar Res 54:1113-1119

Johnson SC, Albright LJ (1991) The developmental stages of Lepeophtheirus salmonis (Krøyer, 1837) (Copepoda, Caligidae). Can J Zool 69:929-950

Johnson SC, Treasurer JW, Bravo S, Nagasawa K, Kabata Z (2004) A review of the impact of parasitic copepods on marine aquaculture. Zool Stud 43:229-243

Jones MW, Sommerville C, Wootten R (1992) Reduced sensitivity of the salmon louse, Lepeophtheirus salmonis, to the organophosphate dichlorvos. J Fish Dis 15:197-202

Lindsay Lord, Rae G (2003) Delivering the solutions-the salmon farmer's point of view. In: Mills D (ed) Salmon at the edge. Blackwell Science, Oxford, p 159-171

Nagasawa K (2001) Annual changes in the population size of the salmon louse Lepeophtheirus salmonis (Copepoda: Caligidae) on high-seas Pacific salmon (Oncorhynchus spp.), and relationship to host abundance. Hydrobiologia 453/454:411-416

Neff BD, Pitcher TE (2002) Assessing the statistical power of genetic analyses to detect multiple mating in fishes. J Fish Biol 61:739-750

Pike AW, Wadsworth SL (1999) Sealice on salmonids: their biology and control. Adv Parasitol 44:233-337

Rae GH (2002) Sea louse control in Scotland, past and present. Pest Manag Sci 58:515-520

Revie CW, Gettinby G, Treasurer JW, Rae GH, Clark N (2002) Temporal, environmental and management factors influencing the epidemiological patterns of sea lice (Lepeophtheirus salmonis) infestations on farmed Atlantic salmon (Salmo salar) in Scotland. Pest Manag Sci 58:576-584

Ritchie G (1997) The host transfer ability of Lepeophtheirus salmonis (Copepoda: Caligidae) from farmed Atlantic salmon, Salmo salar L. J Fish Dis 20:153-157

Ritchie G, Mordue AJ, Pike AW, Rae GH (1996a) Observations on mating and reproductive behaviour of Lepeophtheirus salmonis, Krøyer (Copepoda: Caligidae). J Exp Mar Biol Ecol 201:285-298

Ritchie G, Mordue AJ, Pike AW, Rae GH (1996b) Morphology and ultrastructure of the reproductive system of Lepeophtheirus salmonis (Krøyer, 1837) (Copepoda: Caligidae). J Crustac Biol 16:330-346

Sevatdal S, Copley L, Wallace C, Jackson D, Horsberg TE (2005) Monitoring of the sensitivity of sea lice (Lepeophtheirus salmonis) to pyrethroids in Norway, Ireland and Scotland using bioassays and probit modelling. Aquaculture 244:19-27

Siefkes MJ, Bergstedt RA, Twohey MB, Li W (2003) Chemosterilization of male sea lampreys (Petromyzon marinus) does not affect sex pheromone release. Can J Fish Aquat Sci 60:23-31

Simmons LW (2001) Sperm competition and its evolutionary consequences in the insects. Princeton University Press, Princeton, NJ

Simmons LW, Siva-Jothy MT (1998) Sperm competition in insects: mechanisms and the potential for selection. In: Birkhead TR, Møller AP (eds) Sperm competition and sexual selection. Academic Press, London, p 341-434

Strassmann JE, Solís CR, Peters JM, Queller DC (1996) Strategies for finding and using highly polymorphic DNA microsatellite loci for studies of genetic relatedness and 
pedigrees. In: Ferraris JD, Palumbi SR (eds) Molecular zoology. Advances, strategies, and protocols. Wiley-Liss, New York, p 163-180

Todd CD, Walker AM, Hoyle JE, Northcott SJ, Walker AF, Ritchie MG (2000) Infestations of wild adult Atlantic salmon (Salmo salar L.) by the ectoparasitic copepod sea louse Lepeophtheirus salmonis Krøyer: prevalence, intensity and the spatial distribution of males and females on the host fish. Hydrobiologia 429:181-196

Todd CD, Walker AM, Ritchie MG, Graves JA, Walker AF (2004) Population genetic differentiation of sea lice (Lepeophtheirus salmonis Krøyer) parasitic on Atlantic and Pacific salmonids: analyses of microsatellite DNA varia-

Editorial responsibility: Roger Hughes (Contributing Editor), Bangor, UK tion amongst wild and farmed hosts. Can J Fish Aquat Sci 61:1176-1190

Tregenza T, Wedell N (2000) Genetic compatibility, mate choice and patterns of parentage: invited review. Mol Ecol 9:1013-1027

Tully O, Nolan DT (2002) A review of the population biology and host-parasite interactions of the sea louse Lepeophtheirus salmonis (Copepoda: Caligidae). Parasitology 124: S165-S182

Twohey MB, Hanson LH, Heinrich JW, Seelye JG, Bergstedt RA, McDonald RB, Christie GC (2003) History and development of the sterile male release technique in sea lamprey management. J Gt Lakes Res 29:410-423

Submitted: February 23, 2005; Accepted: May 18, 2005 Proofs received from author(s): October 14, 2005 